\title{
PENSANDO SOBRE A INFLUÊNCIA DA ESTÉTICA POSITIVISTA NA POÉTICA DE GENERINO DOS SANTOS
}

Isabela Melim Borges ${ }^{1}$

\begin{abstract}
Resumo: Este artigo tem como objetivo trazer e discutir algumas produções poéticas de Generino dos Santos (1849-1877) sob a ótica da filosofia positivista proposta por Auguste Comte, da qual foi seguidor confesso. Entretanto, inserida na imensa obra filosófica e política que Comte deixa de legado para toda uma civilização, estava a sua estética, ou: Aptitude Esthétique du Positivisme. É a partir desses pensamentos do filósofo francês que discutirei alguns poemas do escritor citado. Para tal, considero uma produção dividida entre eclética e plural: a primeira, sumariamente, seria a submissão da escrita poética à diversidade literária daquele período, sem que o literário assumisse de fato a primazia, sem que fosse ele o condutor dessa incorporação da diversidade de temas, de vocabulários e até de conceitos (filosófico e científicos). Por pluralidade, ao contrário, entendo justamente a submissão dessa diversidade de elementos não-literários ao literário, de modo que todo elemento extra-literário, quando trazido ao plano literário passa a funcionar diversamente do que faz quando se encontra em seu contexto original.
\end{abstract}

Palavras-chave: Estética positivista; poesia; história literária; Generino dos Santos

Durante a virada so século XIX para o XX, a transformação no campo das ideias literárias brasileiras tinha como alvo questionar o Romantismo, ao mesmo tempo em que preconizava (e partia do) o declínio da Metafísica. Não haveria mais lugar para o idealismo (entendido aí tanto no sentido literário, quanto no filosófico) e tudo estaria sob o jugo da razão. Para a filosofia comtiana, no mundo moderno racional-positivista não caberia mais o tipo de subjetividade que o Romantismo ditou. Na primeira parte do seu Catecismo positivista, Auguste Comte inspirou uma receita que parcela importante da arte e do pensamento ocidental de finais do século XIX aproveitaria para tentar enterrar toda subjetividade romântica que ainda imperava. Para o filósofo, "a nossa verdadeira liberdade resulta essencialmente de uma digna submissão" (1988, p. 106), é a subjetividade que se sobressai à objetividade, diferente, portanto, da subjetividade romântica: "a diferença essencial entre a nova subjetividade e a antiga deve consistir em que aquela será plenamente sentida e confessada, sem que ninguém a confunda jamais com a objetividade" (1988, p. 106).

${ }_{1}^{1}$ Doutoranda em Literatura Brasileira pela UFSC. Mestre em literatura brasileira também pela UFSC, integrante do Núcleo de Pesquisa em informática, literatura e linguística (NuPILL).

Revista de Letras JUÇARA, Caxias - Maranhão, v. 03, n. 02, p. 269 - 290, dez. 2019| 269 
É no texto Aptitude Esthétique du Positivisme ${ }^{2}$ que o filósofo apresenta a ideia: "razão não deve apenas se subordinar ao sentimento para ajudá-lo a dirigir a atividade; ela tem também que, sem se permitir ser dominada pela imaginação, estimulá-lo regulando-o"3. Assim, podemos aceitar que a razão, para Comte, é vista de duas maneiras que se complementam: ela é subordinada ao sentimento e dirige a atividade; e estimula a imaginação regulando o sentimento.

O filósofo francês afirma que o Positivismo, por subordinar a razão ao sentimento, deve e necessita desenvolver nossas faculdades estéticas, justificando que a afeição, vista por ele como uma união de todos os sentimentos, altruístas e egoístas, é a característica humana mais modificável e idealizável, portanto a mais incompleta e passível de imperfeições. Para ele, a poesia, classificada como arte por excelência, seria capaz de modificar nossos sentimentos. Nas palavras dele:

Se nós não separamos dela a eloquência, que é, na verdade, apenas um primeiro rascunho da poesia, muitas vezes abortado, ela exerce especialmente a ação mais difícil e decisiva, para excitar ou acalmar nossas paixões, não improvisadamente, mas seguindo suas leis naturais. Ela se torna então um poderoso auxiliar da moral, como sempre se aceitou. Nada é, portanto, mais motivado do que seu caráter relativo à ação mais do que à especulação, pois ela, a poesia, tem em vista sobretudo o aperfeiçoamento mais geral e mais importante diante do qual as artes materiais, físicas e mesmo intelectuais são apenas secundárias ou preparatórias apesar da eficácia própria a estas (1907, p. 303). ${ }^{4}$

2 Escrito entre 1851 e 1852, apresentou pela primeira vez suas ideias sobre arte e um prelúdio de teoria estética, que foi melhor organizada no primeiro volume do Système de Politique Positive, com o texto: Aptitude Esthétique du Positivisme. No entanto, no livro Catecismo Positivista, publicado em 1852, Comte também discute sobre a arte.

3 CINQUIĖME PARTIE- APTITUDE ESTHÉTIQUE DU POSITIVISME 119. - "Le positivisme et l'art", p. 290. Tradução nossa. Disponível em: https://gallica.bnf.fr/ark:/12148/bpt6k56856891.textelmage, Acesso em: 04/04/2019.

$4 \mathrm{Si}$ on n'en sépare pas l'éloquence, qui n'en est, au fond, qu'une première ébauche, trop souvent avortée, elle exerce spécialement l'action la plus difficile et la plus décisive, pour exciter ou calmer nos passions, non pas à son gré, mais suivant leurs lois naturelles. Elle devient alors un puissant auxiliaire dé la morale, comme on l'a toujours senti. Rien n'est donc mieux motivé que son titre relative à l'action plutôt qu'à la spéculation, puisqu'elle a surtout

en vue le perfectionnement le plus étendu et le plus important, envers lequel les arts matériels, physiques, et même intellectuels, ne sont que secondaires ou préparatoires, malgré leur efficacité propre.

Revista de Letras JUÇARA, Caxias - Maranhão, v. 03, n. 02, p. 269 - 290, dez. 2019| 270 
Assim, a poesia, para o filósofo, seria a arte mais geral e menos técnica, já que seu domínio seria mais extenso por abranger toda a nossa existência pessoal, doméstica e social. A arte poética seria, portanto, mais popular do que qualquer outra, primeiramente porque ela recuperaria os nossos atos e, especialmente, os nossos sentimentos e os devolveria aos nossos pensamentos e, em segundo lugar, ela poderia se referir às nossas concepções mais abstratas sem tentar formulá-las, embelezando-as apenas; e então, pela natureza de seus meios de expressão, retirados da língua habitual, ela seria inteligível a todos.

Também, a poesia requereria o amparo simultâneo da contemplação, da idealização e da expressão. Segundo Luís Lagarrigue ${ }^{5}$, esses três elementos estariam em contínuo processo de aperfeiçoamento, porém, os resultados dos seus respectivos refinamentos deveriam almejar a completa moralização que somente o Positivismo poderia oferecer, permitindo ao poeta viver em um "verdadeiro paraíso", contemplando apenas o bem, idealizando o verdadeiro e expressando o Belo. Lagarrigue, assim como Comte, admite que, quando o poeta não obedece a nenhuma das três condições, suas obras são antiestéticas, pois, dependendo da natureza que estimula o sentimento, as contemplações poderiam ser boas ou más. Ele admite que a tristeza, a dor, podem ser boas contemplações quando despertam nossos sentimentos altruístas e, pelo contrário, a felicidade não valeria a pena ser contemplada se produzisse sentimentos ruins, egoístas (LAGARRIGUE, 1890, p. 8 -9). Assim, a expressão poética, segundo a doutrina comteana e validada por Lagarrigue, se destinaria a completar a contemplação e a idealização, generalizando-as e aspirando, com isso, à unidade coletiva.

É a partir dessas ideias que discutiremos a poesia de Generino dos Santos que se situa na virada do século XIX para o XX, momento repleto de teorias evolucionistas

5 Propagandista do Positivismo e engenheiro, do Chile, publica: La Poesia Positivista: carta a Don Guillermo Puelma Tupper, também chileno, em 1890. A carta veio à luz, provavelmente depois de este último, que era médico, jornalista e político, divulgar seu livro: Un Poema, em 1889, totalmente influenciado pela filosofia positivista.

Revista de Letras JUÇARA, Caxias - Maranhão, v. 03, n. 02, p. 269 - 290, dez. 2019| 271 
e progressistas, tanto no que tange à história das ideias como às várias correntes literárias deste período.

\section{Sobre Generino dos Santos}

O nome Generino estava em uma nota de rodapé no livro $A$ literatura brasileira, volume 1, de José Aderaldo Castello, que explicitava algumas afirmações de Silvio Romero sobre quem havia participado de uma "primeira reação ao Romantismo no Brasil" (2004, p. 283). Segundo Romero, houve um movimento de renovação que foi iniciado no Recife - a chamada Escola do Recife - a partir de 1862: "invadindo a década de 70, o "realismo" de Celso de Magalhães, Generino dos Santos e Sousa Pinto [...]" (idem). À medida que a leitura do livro de Castello avançava, deparamo-nos mais vez com aquele nome, porém, dessa feita, atrelado ao de Martins Júnior, este, autodenominado poeta "científico-filosófico".

Depois de ampla busca nos compêndios de história da literatura, pudemos constatar que Generino dos Santos aparece de forma acanhada. Não o encontramos em Bosi, em Antonio Candido, em Afrânio Coutinho, Sodré, em Ronald de Carvalho, em Luciana Stegagno-Picchio, porém Wilson Martins o cita tanto na sua História da inteligência brasileira (2010), quanto em A crítica literária no Brasil (1983). Neste, Martins cita Generino, quando o compara com o Martins Júnior de Visões de Hoje: "Nem Generino dos Santos, n’Os Lázaros, nem Sílvio Romero nos Cantos do Fim do Século, nem Múcio Teixeira dos Novos Ideais, nem Costa Sena, nem Teixeira de Souza, nenhum deles se elevou tão alto" (1983, vol. 1, p. 243).

Generino teve uma relevante participação na vida intelectual/ jornalística brasileira: foi diretor e fundador de dois periódicos pernambucanos - O Diabo a quatro: revista infernal e $O$ Trabalho - além de ter colaborado com muitos jornais e revistas de grande circulação do eixo Rio-São Paulo.

Para além desses dois periódicos, Generino dos Santos, que se formou em direito pela Faculdade do Recife em 1871, teve uma considerável participação em jornais e em revistas dentro e fora do Pernambuco. Entre os de maior circulação estão: 
Diário de Notícias (RJ), Diário de Pernambuco, Gazeta de Notícias (RJ), Gazeta Nacional, Jornal do Comércio (RJ) Fon-Fon, Dom Casmurro, Novidades, O Besouro. Além de outros, que não circulavam tanto, como: A Província (PE), A Província do Espírito Santo (ES), Brazil Americano (RJ), A Terra da Redenção (RJ), A Academia de São Paulo (SP), Correio Paulistano (SP), Gazeta de Petrópolis (RJ), Gazeta de Campinas (SP), O Monitor (BA), O Mequetrefe (RJ), entre outros. Em todos esses veículos havia publicações de e sobre Generino dos Santos, o que demonstra cabalmente que o poeta foi lido na Bahia, em Pernambuco, no Espírito Santo, no Rio de Janeiro e em São Paulo (capital e interior), ou seja, o poeta parece ter sido razoavelmente conhecido pelo meio intelectual e literário da época.

\section{O Positivismo na poesia de Generino dos Santos}

Sabemos que todo relato histórico é sempre marcado por um certo grau de arbitrariedade, intimamente vinculado às escolhas e ao próprio desejo do historiador, no caso, eu. A subjetividade do historiador, ao conceber e organizar o seu relato, interfere nas opções por ele assumidas e, não raramente, no lugar mais ou menos importante que concede a autores e obras, como é o caso do esquecido Generino. Flora Süssekind vê o historiador como uma espécie de urubu: "seja porque ele devora detritos, ajudando a mantê-los esquecidos; seja porque, ao revirar o lixo, deixa que apareçam muitos restos dos quais uma sociedade se esforça assepticamente por se livrar, cabe ao historiador vestir essa fantasia de abutre e romper os mecanismos que fazem de certos personagens e fatos história; de outros, lixo. " (1983, p. 8).

Às vezes esse "lixo" aparece até meio ao acaso, como aconteceu comigo. Quando, na Biblioteca Nacional, eu estava a procurar os Poemas Modernos de Generino - na seção de obras raras - fui surpreendida quando o diretor das obras gerais me disse que tinha mais coisas do poeta que eu procurava. Eram as Humaníadas, das quais eu nunca tinha ouvido ou lido qualquer palavra. 
Sobre todo esse "lixo" que encontrei, busquei em Flora Süssekind uma estratégia para trabalhar a problemática que o envolve: "Às vezes é todo um período que deve ser reavaliado, às vezes a caracterização de um gênero literário, às vezes 0 perfil de uma geração histórica" (1983, p. 10). Aqui, neste caso, são alguns poemas de Generino que passarei a analisar com o intuito de reavaliar se há, de fato, a presença de algum Positivismo naquela poesia e, se sim, como ela se manifesta: se na forma eclética, já definida no início deste artigo, ou seja, como uma submissão da escrita poética à diversidade literária daquele período, sem que o literário assumisse de fato a primazia, sem que fosse o condutor dessa incorporação da diversidade de temas, de vocabulários e até de conceitos (filosófico e científicos); ou se na forma plural, que, ao contrário da eclética, implica a submissão da diversidade de elementos não-literários ao literário, de modo que todo elemento extra-literário, quando trazido ao plano literário passa a funcionar diversamente do que faz quando se encontra em seu contexto original.

Logicamente, por ser inviável (tampouco necessária) a análise da totalidade da obra que tenho em mãos aqui, comecemos por poemas do livro primeiro de Generino, Paisagens, que consta do volume I das Humaníadas:

\footnotetext{
OS INFINITAMENTE GRANDES

Herschel! prestas-me em vão tua luneta! Vejo-os a olhos nus por toda parte: Desde a alva Lua ao avermelhado Marte, Desde o asteróide ao irregular cometa.

Sou do hemisferio austral deste Planeta Que tem a via lactea a gloriar-te, O' sol; e não preciso analisar-te A fotosfera para ser poeta.

Bem sei que és centro de imortal sistema, Onde, às leis da atração, se vão movendo Astros sem conta em luminoso esquema.

E me sinto maior se te estou vendo: Gloria a ti, que és o autor deste poema Que com letras de luz vais escrevendo.
}

Revista de Letras JUÇARA, Caxias - Maranhão, v. 03, n. 02, p. 269 - 290, dez. 2019| 274 
(SANTOS, 1938, p. 5)

Com a data de $1890^{6}$, Paisagens se abre num soneto que utiliza uma das grandes invenções de século anterior, como é o caso do telescópio (1789) do astrônomo britânico William Herschel, cada vez mais usadas na ciência da época do poeta, para, ao mesmo tempo, renunciar a ele. De acordo com o eu-poético, não há a necessidade de utilizá-lo para ver e compreender os grandes astros do universo, pois o olho do poeta já é o bastante. O eu-poético se refere à fotosfera, ao Sol como centro do universo, à Via-Láctea e, mesmo assim, deixa claro que ele não precisa de tanto para ser poeta. Ser poeta parece transcender a grandeza do universo a tal ponto que ele se funde ao astro rei para poder escrever em "letras de luz".

Toda essa temática ou imagética científica (o poeta como observador das estrelas que se funde com o universo para melhor descrevê-lo), não é mérito apenas de Generino. O que está em questão aqui é como nosso poeta utiliza o cientificismo atrelado às "Novas Ideias" e, por que não dizer, ao Positivismo (tão vinculado à visão das descobertas científicas como um progresso da humanidade) para se expressar poeticamente. Também o próprio Sol, nesse poema, pode ser entendido como uma metáfora do novo século e, portanto, da luz que banha a nova poesia, não mais aquela que se pretendia obscura e triste, como a romântica.

\footnotetext{
A BALADA DA LUA

Quando, no fino azul, translúcido e saudoso,

Da noite vai-se a lua erguendo lentamente,

- Facho elétrico aceso em globo incandescente,

Que após se vai deixando um rasto luminoso;

Eu gosto de ir por ele, a sós, tranquilamente,

Seguindo-a - homem-batel - sobre o elemento undoso:

Cuido-a Pandora então, do seio malicioso,

A jorrar nostalgia em pedraria ardente.
}

6 Data escrita no poema; a maioria dos poemas de Generino estão datados. Não esquecer que, quem ordenou - seu testamenteiro - os poemas, seguiu mais ou menos o tema que os percorre como um todo e não a sua cronologia.

Revista de Letras JUÇARA, Caxias - Maranhão, v. 03, n. 02, p. 269 - 290, dez. 2019| 275 
E eu me lembro de vós, noites da minha terra,

Alvas noites de luar mais alvas do que o dia,

Noites de Agosto, em que, refrata, a luz aberra

E no Capibaribe espelha a imagem tua,

- Lacustre capital onde habita a poesia...

E - Maturino - eu rimo a balada da lua.

(SANTOS, Paisagens, 1938, p. 21)

Em "A Balada da lua", o eu-poético vai descrevendo aquilo que vê, mas de maneira saudosista: é o poeta retratando a lua que se reflete no Capibaribe, rio de Pernambuco, estado natal do poeta. Trata-se de elemento bastante representativo do que Flora Süssekind dizia em seu Cinematógrafo sobre textos retratarem o exterior como uma fotografia intimista: são poemas que tendem ao "enquadramento peculiar", que apontam para "recantos fora do mundo, esconderijos da individualidade" (2006, p. 121). É da imagem da lua refletida no rio que o eu-poético, solitário, extrai a sua poesia, potencializando, pois, o seu próprio interior como um refúgio da "aura". Flora desenvolve ainda essa questão:

Mais paisagens íntimas, portanto, à medida que se torna mais nítida a nova fachada urbano-industrial. Mais história e lembranças pessoais, quanto maior é a percepção do tempo como instante. É como resposta enviesada ao horizonte técnico que se projeta em fins do século XIX que se pode entender, então, em parte, essa multiplicidade de interiores e esse desenho que se deseja em profundidade, em perspectiva, do sujeito lírico (2006, p. 123).

Ora, essa visão de mundo, por parte do poeta, não seria contrária à visão de progresso que o Positivismo tanto pregava? Sim, pois Comte compara a sociedade a um organismo biológico, no qual nenhuma parte tem existência independente, o que já divergiria de um eu-poético solitário e individualista, como o que está presente nesse poema, a exemplo do verso: Eu gosto de ir por ele, a sós, tranquilamente. O eupoético, nesses versos, observa uma paisagem em que há o reflexo da lua, que se transforma em rio navegado pelo "homem-barco", chegando, então, até o reflexo da lua no rio Capibaribe, preso na lembrança desse eu-poético. Esse rio pode ser Revista de Letras JUÇARA, Caxias - Maranhão, v. 03, n. 02, p. 269 - 290, dez. 2019| 276 
entendido metaforicamente como o tempo, segundo a tradição que começa com Heráclito - uma imagem do tempo que vai e não volta (ninguém se banha na mesma água duas vezes). Admitindo então que o tempo que passa e que não volta é o tempo da humanidade, portanto, o do Positivismo, e que o tempo que é retido na memória é o tempo do indivíduo, não fica difícil concluir que esse eu-poético, nesse poema, insere-se no segundo e, portanto, contraria o preceito de coletividade e o tempo da humanidade, do Positivismo. Ora, esse mecanismo desenvolvido pelo eu-poético estaria, de alguma forma, ligado às definições de ecletismo e pluralismo que propomos? Como forma de explicitar o que entendemos por esses termos, tomemos uma das ideias de Paul Valéry sobre a poesia, em "Poesia e pensamento abstrato":

\begin{abstract}
Vocês já notaram, certamente, este fato curioso, de que tal palavra, perfeitamente clara quando a ouvem ou empregam na linguagem normal, não oferecendo a menor dificuldade quando comprometida no andamento rápido de uma frase comum, torna-se magicamente problemática, introduz uma resistência estranha, frustra todos os esforços de definição assim que vocês a retiram de circulação para examiná-la à parte, procurando-lhe um sentido após tê-la subtraído à sua função momentânea? (1999, p. 194-195).
\end{abstract}

Valéry, chama a atenção para uma determinada palavra que, utilizada em determinado contexto pode causar um estranhamento, tornando-se, dessa maneira, problemática. No entanto, o poeta francês admite que se pegarmos essa mesma palavra e a analisarmos à parte do contexto original, seu sentido poderá ser diferente. Pensando dessa maneira, ou seja, a partir de determinados vocábulos que o poeta utiliza, e de que modo ele os utiliza, passamos a entender a poesia em si, já que ela é arte da linguagem, cujas combinações de palavras produzem emoções que outras combinações não as produziriam. Com isso exposto, podemos afirmar que a verdadeira poesia feita por Generino, isto é, aquela em que os elementos extraliterários se fundem ao literário, ou seja, de maneira plural, se dá no campo lexical. São as palavras do campo lexical do Positivismo, como por exemplo a palavra "tempo" que, pensada dentro daquela filosofia faria menção a um tempo eterno e evolutivo. Essa mesma palavra, o "tempo", quando Generino a utiliza de forma diferente da Revista de Letras JUÇARA, Caxias - Maranhão, v. 03, n. 02, p. 269 - 290, dez. 2019| 277 
filosófica, vem produzir outros sentidos capazes de modificar e até mesmo movimentar um poema como um todo dentro do seu próprio tempo: é isso que caracterizamos como pluralismo. Ora, é o caso da utilização de todo e qualquer vocábulo, trazido aos versos de maneira a fazê-la distante de seu campo semântico original (no caso anterior, a filosofia positivista), como ocorre com o vocabulário científico do soneto "Os infinitamente grandes". Essas divergências, produzindo um sentido diferente do original, ao transformar o semântico através de sua inserção no poético, são capazes de provocar uma emoção que originalmente não apareceria, são elas que apontam para o que estamos entendendo como pluralismo. De modo oposto, isto é, quando os elementos ou vocábulos inerentes ao Positivismo se mantêm no mesmo campo semântico de seu original filosófico, não havendo qualquer mudança de sentido dentro do poema, temos a poesia eclética. Vejamos como o poeta trata o "tempo" no poema abaixo:

\author{
NO TEMPO E NO ESPAÇO \\ O tempo foge, instante após instante, \\ Minuto após minuto, hora após hora; \\ E' noite quase, mal começa a aurora; \\ Mal finda a noite, o dia está distante. \\ E, assim, fugindo, em sucessão constante, \\ Dia após dia, mês após mês, anos em fora, \\ Se vai o tempo e séculos devora, \\ Sem nunca mais volver, um só instante! \\ Ah! Nunca mais! Que o tempo — outro Saturno \\ Vai devorando quanto há produzido \\ E a si mesmo devora por seu turno. \\ E' bem feliz, quem tendo assaz sofrido \\ Do tempo o rigorismo diuturno, \\ Ao tempo houver por fim sobrevivido!
}

(SANTOS, Alma positivista, p. 15)

O eu-poético, nos dois quartetos do soneto acima, trata de um tempo fugidio, rápido, constante, que pode ser sintetizado nestes versos:

Revista de Letras JUÇARA, Caxias - Maranhão, v. 03, n. 02, p. 269 - 290, dez. 2019 | 278 
Se vai o tempo e séculos devora,

Sem nunca mais volver, um só instante!

Podemos afirmar que ele, o eu-poético, está se referindo ao tempo da humanidade, que admitimos positivista, aquele que passa e não volta, diferentemente do tempo que expressou no soneto anterior, o tempo do indivíduo. Entretanto, no terceto seguinte há uma terceira espécie de tempo:

Vai devorando quanto há produzido

E a si mesmo devora por seu turno.

É o tempo que devora a si mesmo, numa circularidade, que anda para não sair do lugar. É um tempo mítico, regido por outro sistema que não a racionalidade pura e linear. O eu-poético nos fala agora de um tempo que fere a certeza cartesiana das palavras - parece que tudo o que ele nos disse sobre o próprio tempo até agora, nesse soneto, foi colocado em xeque, como se ele nos dissesse que não devemos acreditar no que está escrito, apesar dos versos anteriores, em que indica um tempo preciso e lógico. Surge, assim, uma noção de tempo diferente das duas anteriores, aquelas que tratam do tempo individual e do tempo da humanidade, no que parece ser claramente um terceiro conceito de tempo: o mítico.

A seguir, mais uma amostra de como o tempo é trabalhado pelo eu-poético de Generino dos Santos:

Como enorme oceano que se estende

E flui de cada berço à sepultura,

Em sucessão contínua o tempo ascende:

- Não tem começo e eternamente dura.

[...]

Corre - e não para nunca! — embora tente

Detê-lo - um só momento! — o mais ousado:

- Consigo o arrasta a indômita corrente!

Que o tempo - inda ao nascer - eternizado,

Se, um momento, alguém cuida que é - presente -

Revista de Letras JUÇARA, Caxias - Maranhão, v. 03, n. 02, p. 269 - 290, dez. 2019 | 279 
Vê que, n'esse momento, é já passado! —

(SANTOS, sem título, Alma positivista, p. 14)

Novamente, o eu-poético fala aqui de um tempo, que, comparado ao oceano, flui desde o nascimento até a morte do ser. Mas, novamente há algo aqui que envereda pelo adverso, pelo contrário, pois o tempo comparado ao oceano pressupõe algo infinito, que vai além da morte, desacordo evidenciado nos dois últimos versos do primeiro quarteto:

Em sucessão contínua o tempo ascende:

- Não tem começo e eternamente dura.

Esse mesmo eu-poético admite um tempo que, em contínua sucessão, não tem começo e dura eternamente, desdizendo assim o que afirmou logo antes, isto é, que se inicia com o nascimento (berço) e termina com a morte (sepultura). O tempo é considerado, pelo eu-poético, uma "corrente indomada" que, por isso, não há como ser detido, pois, no momento em que se o vê, já não existe mais, é o tempo que se devora, o tempo infinito, mítico. Podemos pensar nesse tempo mítico tal qual o Oroborus, figura da serpente que come a sua própria cauda, como sinônimo de movimento, de continuidade, de autofecundação e, portanto, de eterno retorno, como esse tempo do poema, que sempre volta, eternamente.

A partir daí, podemos afirmar que Generino, quando nos oferece poemas trazendo algum elemento (pretensamente) positivista, como o "tempo da humanidade", acaba ultrapassando-o, nos mostrando também, nesse caso, o tempo do indivíduo e o tempo mítico. Ora, essa superposição de temporalidades divergentes só é possível no espaço poético, pois associa ao vocábulo "tempo" um sentido diferente do seu original filosófico, o que reafirma, mais uma vez, o que estamos entendendo como pluralismo na obra do poeta.

Ainda sobre os eu-poéticos e as temporalidades expressadas, é necessário lembrarmos que, para Comte, num estágio positivo, próximo, portanto, da perfeição, 
não haveria lugar para o individualismo, apenas para o desenvolvimento da solidariedade e do altruísmo de cada um em favor da coletividade. Já no que se refere à poesia, para o filósofo francês, esta requereria o suporte progressivo da contemplação, da idealização e da expressão, almejando uma completa moralização, permitindo ao poeta viver em um "verdadeiro paraíso", contemplando apenas o bem, idealizando o verdadeiro e expressando o Belo. No caso específico do poema "A balada da lua", propor um sentido de moralização seria bastante forçado, uma vez que nada há, nele, que possa ser tomado como evidente elemento moralizador. Vale lembrar aqui que o intuito "moralizador" implica, segundo Comte, uma elevação dos sentimentos altruístas, tanto do poeta quanto do leitor. Para atribuir tais sentidos a esses versos, o leitor teria de forçar bastante a leitura, enveredando por uma interpretação que não seria exatamente leitura literária como a entendemos há décadas, mas uma adequação dos sentidos possíveis do poema a campos semânticos exteriores ao próprio poema. De outro lado, não só os escritos de Generino mas os de outros poetas que não estão, necessariamente, sob o jugo dos preceitos positivistas, poderiam despertar as nossas melhores emoções, nossos sentimentos altruístas. Essa visão de que a arte positivista seria a única, segundo o filósofo francês, capaz de despertar tais sentimentos, não se sustenta, visto que muitos outras poéticas já se mostraram (e se mostram) capazes de despertar tais emoções.

Por seu turno, o volume terceiro de Humaníadas é composto de um único livro, Imortalidade Subjetiva, que, de acordo com a religião positiva, é compreendida como a sobrevivência de grandes homens na memória de uma sociedade. A partir disso, Generino, entre os muitos homenageados desse livro, escreveu, ao menos, uma meia dúzia de sonetos para o seu sobrinho, Augusto dos Anjos. Trazemos aqui um exemplar:

AERE PERENNIUS

Em vida e sobre o livro do jovem, extraordinário

e originalíssimo poeta materialista, Augusto dos Anjos, "Eu"

Eu li teu livro - um Haeckel bem rimado

Revista de Letras JUÇARA, Caxias - Maranhão, v. 03, n. 02, p. 269 - 290, dez. 2019| 281 
Em que o humano ser se anatomiza

$E$ reduz à histológica divisa

Que não transpõe o ser organizado.

E, como observador atordoado

Que de um laboratório se desliza,

Levando do "não ser" noção precisa -

— Por ambos nós! —- fechei-o, desolado.

Pois que! Buscas fenômenos da vida

Na primitiva célula ou monera,

Da viva carne em carne apodrecida?

E a função cerebral que a anima e gera

Todo o bem, todo o amor, que a amar convida!

— Não pode ser! - Teu Haeckel degenera!

(SANTOS, Imortalidade Subjetiva, 1938, p. 100)

"Exegi monumentum aere perennius", disse Horácio na Ode 3, 30, que, segundo a tradução de Haroldo de Campos, significa "ergui um monumento mais perene do que o bronze" (1998, p. 35). É a partir dessa premissa que Generino inicia seu soneto, afirmando, portanto, a eternidade de Augusto dos Anjos na literatura, tratando uma vez mais da questão do tempo. É na contradição, mais uma vez, que Generino poetiza sobre o tempo. Baseando-se numa eternidade positivista, ele renega a materialidade da morte defendida por Haeckel e trazida por Augusto dos Anjos no seu livro, EU. Mas o faz de maneira peculiar, ou seja, do campo semântico científico traz os seguintes vocábulos: humano, anatomiza, histológica, laboratório, primitiva célula, monera, carne viva, carne apodrecida, função cerebral, degenera. Entretanto, esses vocábulos perdem o seu significado original e são re-semantizaados no poema quando, por meio deles o eu-poético aborda o tempo da humanidade em contraposição com o tempo do materialismo que impera na poesia de Augusto dos Anjos, para, ao final, tratar do tempo da poesia como um movimento entre esses dois outros.

Além do tempo tratado no poema, o eu-poético proposto por Generino "conversa" com a poesia de Augusto dos Anjos, dizendo que seu EU seria um Haeckel "bem rimado" (observemos aqui a aproximação proposta pelo poeta: Haeckel e rima Revista de Letras JUÇARA, Caxias - Maranhão, v. 03, n. 02, p. 269 - 290, dez. 2019 | 282 
são dois vocábulos de campos semânticos e lexicais totalmente diferentes, mas que funcionam bem dentro do poema). Com isso, estaria ele menosprezando a poesia do sobrinho? Saindo da discussão poética e entrando na filosófica, acreditamos que, por não concordar com o materialismo de Haeckel, já que contraria as ideias positivistas, Generino traz alguns elementos da filosofia alemã como a noção do "não ser" e a da busca de vida em "carne apodrecida", sem se conformar com as escolhas do poeta paraibano. Contudo, há uma contradição entre o título do poema, que prega algo eterno/perene relacionado ao pensamento positivo (que crê na imortalidade da alma e no culto aos mortos por conta do legado que deixaram para a humanidade, considerados eternos, o tempo e o legado), frente a uma visão da morte, presente na poesia de Augusto dos Anjos, que aparece como uma manifestação do pessimismo, como uma "implacável presença da maior das evidências da vida e do universo, [...] destruidora paciente e impiedosa de todos os esforços e devaneios humanos" (BUENO, 1966, p. 23). É Generino, mais uma vez, apontando para a questão do tempo, aqui, do tempo da humanidade, do tempo positivista.

Para que possamos reiterar essa poética plural de Generino, segue aqui mais um exemplo:

NA MORTE DE AUGUSTO DOS ANJOS

O último grande poeta materialista da raça latina

- Vitimado por pneumonia, aos 30 anos de idade, longe de sua

terra natal, no "Nirvana da Leopoldina" do Estado de Minas Gerais.

Volveste, enfim, à plástica matéria

Inorgânica, o orgânico arcabouço

Que fazia lembrar o de um molosso,

Cujo pulmão roesse atroz bactéria!

Ora, sulfúrea chama, deletéria,

De comburentes gazes, sobre um fosso,

- Tão só! nos diz teus ideais de moço...

Áureo esplendor de anímica miséria!

A primitiva célula, que o gênio

Te havia, em ritmos orquestrais, plasmado,

Não te é mais...que ermo balão de oxigênio!

Mas quanto, amando, em verso articulado

Revista de Letras JUÇARA, Caxias - Maranhão, v. 03, n. 02, p. 269 - 290, dez. 2019| 283 
E rebelde a escolástico convênio,

Cantaste... há de, ficar eternizado!

(SANTOS, Imortalidade Subjetiva, 1938, p. 101)

Aqui, Generino, embora aborde o tempo eterno em mais uma contraposição ao tempo materialista defendido por Augusto dos Anjos, aproxima-se do fazer poético do sobrinho: o eu-poético de "Na morte de Augusto dos Anjos", de posse dos vocábulos plástica matéria, inorgânica, orgânica, pulmão, bactéria, sulfúrea, gazes comburentes, todos de um mesmo campo semântico que se refere à ciência, inseridos no poema passam a se comportar de modo diferente do original, à feição do que faz 0 próprio Augusto dos Anjos. Vejamos:

A primitiva célula, que o gênio

Te havia, em ritmos orquestrais, plasmado,

Não te é mais...que ermo balão de oxigênio!

O eu-poético consegue abordar a poesia enquanto vida que se revela ao próprio poeta através dos "ritmos orquestrais". O amor, sinônimo de vida e de eternidade - portanto o "tempo" aqui novamente presente - finaliza o poema suscitando a existência por meio da poesia, mesmo que o eu-poético contra ele se rebele, o que pode ser verificado no terceto abaixo:

Mas quanto, amando, em verso articulado

E rebelde a escolástico convênio,

Cantaste... há de, ficar eternizado!

Trata-se de característica que corrobora, portanto, mais uma vez, a pluralidade na poesia de Generino.

Todos os sonetos que trouxemos até este momento classificamos como plurais, uma vez que os elementos extraliterários se incorporam ao poema, passando, portanto, estes elementos a funcionarem diversamente quando em seu contexto 
original. Porém, Generino dos Santos ficou conhecido como um "poeta positivista" e, a partir de agora, traremos poemas que diferem desses expostos e discutidos até aqui, aproximando-se da receita positivista de poesia.

O livro Alma positivista ("versos de inspiração coentífica e filosófica"), das Humaníadas 3, seria aquele em que Generino se apresenta como tal: um positivista religioso. Vejamos:

\section{NA FESTA DOS MORTOS}

"Et les morts plus et plus gouvernent les vivants."

Silêncio! Vai passar-se um drama augusto. - A História

Abre o seio fecundo, e a crítica moderna

Arranca à escuridão da noite sempiterna

O culto dos avós, cheios de imensa glória.

Não! não finda na campa a vida transitória

Nem tão pouco começa ali a vida eterna:

Se a lei da evolução em tudo nos governa,

A lei da filiação faz-nos viver na História.

Tudo o que o homem pensa e age, arte ou ciência, Desde as leis da atração às leis da consciência,

Transmite gradualmente a seres sucessivos;

E assim é que, por lei da continuidade, Solidária, o que foi, será a Humanidade,

- E os mortos, mais e mais, governam sempre os vivos.

(SANTOS, 1939, p. 64)

O fato de existir um livro cujo título é Alma positivista, não significa necessariamente que nele encontraremos apenas poemas prosélitos, didáticos e utilitaristas, que seriam algo do tipo filosofia em versos. Como já deve ter ficado nítido, o intuito que temos aqui nesta tese é justamente demonstrar que Generino foi completamente influenciado pela filosofia de Comte, e que, apesar disso, incorporou a filosofia na sua poesia de forma plural. Contudo, este trabalho também precisa mostrar e discutir o Generino eclético. Para tanto, entre muitos exemplos, trouxemos 
para análise o poema "Na festa dos mortos", acima, e pretendemos assinalar, através dele, o ecletismo também presente nos versos do poeta recifense.

Num primeiro momento, é preciso recordar que o culto aos mortos é de grande importância para a doutrina positivista, e, nesse caso, enfatizar principalmente se esses mortos têm alguma relevância para a sociedade, como Tiradentes, por exemplo. Segundo Auguste Comte, "Os vivos são sempre e cada vez mais, governados pelos mortos: tal é a lei fundamental da ordem humana"7 (1988, p. 152). E esse é o mote do poema de Generino: a morte dos avós.

"Na festa dos mortos", em termos de artifícios poéticos, podemos afirmar uma parca presença daqueles elementos. Em conformidade com Bosi:

As palavras concretas e as figuras têm por destino vincular estreitamente a fala poética a um preciso campo de experiências que o texto vai tematizando à proporção que avança. Como se, cada palavra, fosse possível ao poeta (e ao leitor) reconquistar, de repente, a intuição da vida em si mesma. As figuras são procedimentos que visam a significar o processo dialético da existência que sempre desemboca no concreto. Mas elas só assumem pleno sentido quando integradas em um todo semântico que dá a cada uma delas a sua "verdade", isto é, a sua co-notação (1977, p. 16).

Sobre as palavras concretas e as figuras que aparecem nesse poema, podemos afirmar que, diferentemente das outras composições de Generino, elas aparecem de forma crua, não precisam ser criadas pelo leitor, já estão completas em si mesmas. Desse modo, o poema não segue um percurso que leva a uma imagem final e que dá sentido a si mesmo. Não há aqui, como quer Bosi, uma "verdade" como um produto final de uma dialética entre as figuras e "todo semântico". Tudo, nesse poema, já está dado, nada precisa ser desvelado. Em suma, Generino, "Na festa dos

7 De acordo com Comte, "para se conceber melhor esta lei, cumpre distinguir, em cada verdadeiro servidor da humanidade, duas existências sucessivas: uma, temporária, mas direta, constitui a vida propriamente dita; a outra, indireta, mas permanente, só começa depois da morte. Sendo a primeira sempre corporal, pode ser qualificada de objetiva; sobretudo por contraste com a segunda, que, não deixando subsistir a cada um senão no coração e no espírito de outrem, merece o nome de subjetiva. Tal é a nobre imortalidade, necessariamente imaterial, que o positivismo reconhece à nossa alma, conservando este termo precioso para designar o conjunto das funções intelectuais e morais, sem nenhuma alusão à entidade correspondente" (1988, p. 152).

Revista de Letras JUÇARA, Caxias - Maranhão, v. 03, n. 02, p. 269 - 290, dez. 2019| 286 
mortos", traz os elementos extraliterários da filosofia positivista, mas não os amalgama ao poema. É nítida a presença deles como objetos fora do seu lugar. Outro exemplo:

\author{
LIBERTANDO \\ À sociedade abolicionista cearense em nome da confraternidade \\ pernambucana \\ "La liberte ne se donne pas, elle se prend." \\ Alfonso Esquiros - Os Mártires da Liberdade. \\ E' assim que se honra a Pátria e a Humanidade: \\ Indo ao lar, arrancando à escravidão a criança, \\ Libertando o adulto, e audaz, co'a segurança \\ Que só o dever produz, trazendo-o à sociedade. \\ Que o escravizou, e após dizendo-lhe: "Descansa; \\ A fera já não vive; o escravo - a propriedade \\ Humana - se extinguiu; - transpondo, a média idade \\ Morreu servo da gleba: este é o homem. Lança \\ Por terra esse mesquinho e errôneo preconceito. \\ Ensina, educa, instrui, liberta, e o escravo há de \\ Tornar-se evoluindo um cidadão perfeito. \\ Basta só no dever fundar-Ihe a liberdade \\ E ter-lhe-ás formado a ideia do direito: \\ - E' assim que se honra a Pátria e a Humanidade. "
}

(SANTOS, Alma positivista, 1939, p. 79).

No soneto acima, podemos observar um eu-poético sem muito destaque, que discorre sobre questões políticas pertinentes, outra vez, ao Positivismo. O mote dos versos é a escravidão, tratada aqui de forma seca, com imagens óbvias, pois são de fácil observação, ação esta que não exige muito empenho do seu leitor. As palavras são, para o poeta, ao mesmo tempo, signos e coisas. E elas designam não apenas coisas, mas também a ação possível dessas coisas. Isso significa que a tendência funcional da linguagem poética é falar não em nível de conceitos (como ocorre neste soneto), mas no nível de realidades, presentificando os objetos denominados e mostrando-os sob um novo e surpreendente aspecto, justamente o que não ocorre em 
"Libertando". Dessa maneira, depreendemos que também com este soneto, Generino se mantém no plano eclético da poesia.

Sobre essa dualidade na obra - ora eclética, ora plural — de Generino, vale ressaltar alguns pontos importantes que Paul Valéry apresenta em "Poesia e pensamento abstrato": [...] "o mesmo eu tem aspectos muito diferentes, que se torna abstrato ou poeta através das especializações sucessivas, das quais cada uma é um desvio do estado puramente disponível e superficialmente em harmonia com o meio externo" [...] (1999, p. 197). Considerando o pensamento de Valéry, e, aplicado à poética de Generino, toda a dualidade existente nela pode ser pensada a partir de uma multiplicidade de sujeitos que se personificam no poeta, ora eclético, ora plural. É através dessa dualidade que, "às vezes, alguma coisa quer se exprimir, às vezes, algum meio de expressão quer alguma coisa para se servir" (1999, p. 210). É exatamente pensando nessa duplicidade que podemos admitir um Generino que usa os versos para expressar sua filosofia, mas que também, e melhor, usufrui da poesia para expressar um estado poético através das palavras, que podem ou não se encaixar no campo semântico da filosofia. Como enfatiza Valéry, o talento do poeta não pode fazer com que a atenção colocada no acompanhamento das ideias (no caso, as positivistas) deixe de concorrer com aquela que "acompanha o canto" (1999, p. 208); é esta tensão, ou, melhor dizendo, concorrência que, se esquecida, deteriora o poema. Generino dos Santos, portanto, foi além da simples filosofia em versos, acabou por ser um poeta que corrigiu, de alguma maneira, o filósofo.

Abstract: This paper aims to bring and discuss some poetic productions of Generino dos Santos (1849-1877) from the perspective of the positivist philosophy proposed by Auguste Comte, that this poet was a confessing follower. However, embedded in the immense philosophical and political work that Comte leaves behind for a whole civilization was its aesthetics, or: Aptitude Esthétique du Positivisme. By these thoughts of the French philosopher, I will discuss some poems of that poet. For this, I consider a production shared between eclectic and plural: the first, summarily, would be the submission of poetic writing to the literary diversity of that period, without the literary actually assuming the primacy, without it being the conductor of this incorporation of the themes' diversity, of vocabularies and even of concepts (philosophical and scientific). By plurality, on the contrary, I mean precisely the submission of this diversity of non-literary elements to the literary, so that every extra-literary

Revista de Letras JUÇARA, Caxias - Maranhão, v. 03, n. 02, p. 269 - 290, dez. 2019| 288 
element, when brought to the literary plane, functions differently than it does when it is in its original context.

Keywords: Positivist aesthetics; poetry; Literature History; Generino dos Santos.

\section{Referências bibliográficas}

ANJOS, Augusto dos. Obra completa. Organização, fixação do texto e notas, Alexei Bueno. Rio de Janeiro: Nova Aguilar, 1994.

BOSI, Alfredo. O ser e o tempo na poesia. São Paulo: Cultrix, 1977.

CASTELLO, José Aderaldo. A literatura brasileira: origens e unidade. São Paulo: Editora da Universidade de São Paulo, 2004.

COMTE, Auguste. Curso de filosofia positiva; Discurso sobre o conjunto do Positivismo; Catecismo positivista; tradução José Arthur Giannotti e Miguel Lemos. São Paulo: Nova Cultural (Os pensadores), 1988.

. Discours sur l'ensemble du positivisme. Source gallica.bnf.fr / Bibliothèque nationale de France, 1907.

FERREIRA, Luzilá Gonçalves (org). Escritores pernambucanos do século XIX. Recife: Cepe, 2010. Volume 2.

LAGARRIGUE, Luis. La poesia positivista: carta dirigida al señor Don Guillermo Puelma Tupper. Santiago do Chile: Imprensa Cervantes, 1890. Disponível em: https://www.bcn.cl/obtienearchivo?id=documentos/10221.1/37600/1/211279.pdf\&orig en=BDigital Acesso em: 23/04/2019.

MARTINS, Wilson. A crítica literária no Brasil. Vol. 1. Rio de Janeiro: Livraria Francisco Alves editores S/A, 1983.

Grossa: Editora UEPG, 2010.

. História da inteligência brasileira. Vol. V (1897-1914). Ponta

SANTOS, Generino dos. Humaníadas: O mundo - A humanidade - $O$ homem; volume 1, "Paisagens" e "Rapsódias pernambucanas". Rio de Janeiro: Tipografia do Jornal do Comércio, 1938.

volume 2, "Alma positivista". Rio de Janeiro: Tipografia do Jornal do Comércio, 1940. 
Humaníadas: O mundo - A humanidade - O homem; volume 3, "Imortalidade subjetiva" e "Mármores e Bronzes". Rio de Janeiro: Tipografia do Comércio, 1938.

SUSSEKIND, Flora. Cinematógrafo de letras: literatura, técnica e modernização no Brasil. São Paulo: Companhia das Letras, 1987. . O sapateiro Silva. Rio de Janeiro: Fundação Casa de Rui Barbosa, 1983.

VALÉRY, Paul. Variedades. Org. e tradução de João Alexandre Barbosa. São Paulo: Editora lluminuras, 1999.

Data da submissão:03/11/2019

Data da aprovação: 15/12/2019

Revista de Letras JUÇARA, Caxias - Maranhão, v. 03, n. 02, p. 269 - 290, dez. 2019 | 290 